\title{
How to preserve and handle fish liver samples to conserve RNA integrity
}

\author{
Eeva-Riikka Vehniäinen ${ }^{1}$ (D) Maiju Ruusunen ${ }^{1} \cdot$ Pekka J. Vuorinen $^{2} \cdot$ Marja Keinänen $^{2} \cdot$ Aimo O. J. Oikari $^{1}$ • \\ Jussi V. K. Kukkonen ${ }^{1}$
}

Received: 28 June 2018 / Accepted: 28 March 2019 / Published online: 22 April 2019

(C) The Author(s) 2019

\begin{abstract}
As transcriptomic studies are becoming more and more common, it is important to ensure that the RNA used in the analyses is of good quality. The RNA integrity may be compromised by storage temperature or freeze-thaw cycles, but these have not been well studied in poikilothermic fishes. This work studied the effects of tissue storage time and temperature, and freeze-thaw cycles of tissue and extracted RNA on RNA integrity in brown trout (Salmo trutta L.) liver. The storage time and temperature had an effect on RNA integrity, but RNA suitable for quantitative reverse transcription PCR (RT-qPCR) (RIN > 7) was still obtained from samples preserved at $-20^{\circ} \mathrm{C}$ for 6 months. Freeze-thaw cycles of tissue or RNA did not compromise the integrity of RNA. RNA degradation had an effect on RT-qPCR results, and the effect depended on gene. The RT-qPCR analysis of historical samples from a bleached kraft pulp mill effluent exposure in 1984 revealed no significant cypla induction. Recommendations are given for the preservation and handling procedures of samples designated for transcriptomic analyses.
\end{abstract}

Keywords Bleached kraft pulp mill effluent · Cytochrome p450 - Liver · Quantitative reverse transcription PCR · RNA integrity · Sample storage

\section{Introduction}

The studies using transcriptomics are becoming more and more common in ecotoxicology. To make sure that the results are trustworthy, it is absolutely crucial to use good-quality RNA in the analyses. The RNA is considered fragile, and the recommendation is to flash-freeze the samples in liquid nitrogen, to preserve them at $-70{ }^{\circ} \mathrm{C}$ or lower, and to avoid freeze-thaw cycles both of the tissue sample and of the extracted RNA (Sambrook and Russell 2001). However, in field conditions these procedures are not always possible, as liquid nitrogen, $-70{ }^{\circ} \mathrm{C}$ freezer, or products like RNA later may not be available. The freeze-thaw cycles of the frozen sample or

Responsible editor: Philippe Garrigues

Eeva-Riikka Vehniäinen

eeva-riikka.vehniainen@jyu.fi

1 Department of Biological and Environmental Science, University of Jyväskylä, P.O. Box 35, FI-40014 Jyväskylän yliopisto, Finland

2 Natural Resources Institute Finland (Luke), P.O. Box 2, FI-00791 Helsinki, Finland the extracted RNA can be avoided by taking subsamples at the time of sampling or RNA extraction. Sometimes, the need for multiple analyses arises only after the sample or RNA has already been preserved in one tube, which necessitates multiple thawing. It is therefore important to know how sample preservation and repetitive thawing affect the integrity of the RNA.

The RNA integrity can be assessed most reliably with microchip gel electrophoresis, using Agilent BioAnalyzer or Bio-Rad Experion (Imbeaud et al. 2005). The BioAnalyzer calculates an RNA integrity number (RIN) for each sample using the electrophoresis results (Schroeder et al. 2006). The RIN is a measure of how intact the RNA is, and it ranges from 1 (totally degraded RNA) to 10 (fully intact RNA) (Schroeder et al. 2006). Several RIN cut-offs ranging from 3.95 to 8 have been proposed for transcriptomic analyses (Fleige and Pfaffl 2006; Gallego Romero et al. 2014; Huang et al. 2013; Ibberson et al. 2009; Imbeaud et al. 2005; Weis et al. 2007).

Studies on the effects of sample handling and preservation on RNA integrity have mainly been conducted on mammalian species, having a normal body temperature ca. $15{ }^{\circ} \mathrm{C}$ higher than room temperature (Bao et al. 2013; Ervin et al. 2007; Micke et al. 2006; Ohashi et al. 2004; Thompson et al. 
2007; Viana et al. 2013; Walter et al. 2006). Poikilothermic cold-water fish thrive in temperatures from near zero close to $20^{\circ} \mathrm{C}$. The only study on fish investigated the effect of room temperature incubation on the quality of RNA in Atlantic salmon (Salmo salar L.) tissues and found that the effect depended on tissue, liver being the tissue with very rapid RNA degradation (Seear and Sweeney 2008). The effects of freeze-thaw cycles of tissue and RNA have only been studied in mammals (Botling et al. 2009; Jochumsen et al. 2007; Thompson et al. 2007), and no published studies exist about storing the samples at $-20{ }^{\circ} \mathrm{C}$.

The aim of this study was to investigate how tissue handling, storage time, storage temperature, and freeze-thaw cycles affect the quality of RNA of fish liver. Liver tissue of brown trout (S. trutta L.) was preserved at room temperature, fridge, normal freezer, deep freezer, or liquid nitrogen for various time periods up to 6 months. In addition, the effect of freeze-thaw cycles on RNA integrity was studied by analyzing RIN after repetitive thawing and freezing liver tissue and purified RNA. The effect of RNA integrity on RT-qPCR results was investigated by room temperature incubation of liver samples, resulting in RNA with varying RINs. RNA was also extracted from historical samples that had been stored for 28 years in liquid nitrogen, and RT-qPCR run for them.

\section{Material and methods}

\section{Tissue sampling and storage}

The new liver tissue samples were taken from six four-yearold male brown trout (Salmo trutta L.) with the mean body weight of $1006 \mathrm{~g}$ in Laukaa fish farm of the Natural Resources Institute Finland (Luke, formerly the Finnish Game and Fisheries Research Institute) in November 2012. The brown trout were taken from water of $<5{ }^{\circ} \mathrm{C}$ and the sampling was performed in a low-temperature room. The fish were stunned with a blow to the head, weighed, and their length was measured, after which they were sacrificed by nuchal break. Livers were removed and cut to 50-100 mg pieces randomly, avoiding connective tissue areas. They were placed in microcentrifuge tubes, and either immediately frozen in liquid nitrogen or kept on ice. In addition, larger liver samples of up to $1.5 \mathrm{~g}$ were taken, and immediately frozen and preserved in liquid nitrogen. The samples were transferred to the University of Jyväskylä (4 h) either in an ice bath or frozen in liquid nitrogen, and then stored at room temperature $(+$ $\left.20{ }^{\circ} \mathrm{C}\right)$, fridge $\left(+4{ }^{\circ} \mathrm{C}\right)$, normal freezer $\left(-20{ }^{\circ} \mathrm{C}\right)$, or deep freezer $\left(-80^{\circ} \mathrm{C}\right)$. The RNA extraction was carried out after $1,5,31$, and 180 ( 6 months) days of storage. The transfer and storage conditions are summarized in Table 1, and the experimental plan is shown in Fig. 1.
Table 1 Transfer (transfer time $4 \mathrm{~h}$ from the sampling to the laboratory) and storage conditions of brown trout livers and the respective RNA integrity numbers (RIN). RIN values represent mean \pm SD of five (marked with \#) or six biological replicates

\begin{tabular}{llll}
\hline Transfer & Storage temperature $\left({ }^{\circ} \mathrm{C}\right)$ & Storage time & RIN \\
\hline Ice & +20 & 1 day & $2.8 \pm 0.4$ \\
Ice & +4 & 1 day & $6.8 \pm 0.7$ \\
Ice & +4 & 5 days & $3.7 \pm 1.7$ \\
Ice & -20 & 1 day & $9.2 \pm 0.3$ \\
Ice & -20 & 5 days & $9.4 \pm 0.3$ \\
Ice & -20 & 31 days & $7.6 \pm 0.3$ \\
Ice & -80 & 5 days & $9.5 \pm 0.3$ \\
Liquid nitrogen & -20 & 1 day & $8.0 \pm 0.4$ \\
Liquid nitrogen & -20 & 5 days & $8.6 \pm 0.8$ \\
Liquid nitrogen & -20 & 6 months & $7.6 \pm 0.4 \#$ \\
Liquid nitrogen & -80 & 5 days & $9.7 \pm 0.3$ \\
Liquid nitrogen & -80 & 6 months & $10 \pm 0.0$ \\
\hline
\end{tabular}

The historical samples originated from a similar exposure as reported in Vuorinen and Vuorinen (1985), but contrary to the previous study, fish were exposed until they were sacrificed. Briefly, five-year-old brown trout of both sexes (the mean body weight $1061 \mathrm{~g}$ ) had been exposed to low, sublethal dilutions $(0.1,0.2$, and $0.5 \%)$ of bleached kraft pulp and paper mill effluents (BKME) or control water for 4 months in July-November 1984. At sampling, the air and water temperatures were $<5{ }^{\circ} \mathrm{C}$. The excised liver samples were immediately frozen in liquid nitrogen. In our study, the RNA was extracted from liver samples that had been preserved in liquid nitrogen for 28 years.

\section{RNA extraction}

The RNA was extracted with Tri reagent (Molecular Research Center) according to the manufacturer's protocol. Pieces of liver $(50-100 \mathrm{mg}$ ) were homogenized with plastic homogenization sticks in $1 \mathrm{ml}$ Tri reagent in microcentrifuge tubes. After $5 \mathrm{~min}$ incubation at room temperature, $200 \mu \mathrm{l}$ chloroform was added and the tube was shaken vigorously. The tubes were let stand for 5 to $15 \mathrm{~min}$ at room temperature, after which they were centrifuged $\left(12,000 \times g, 15 \mathrm{~min},+4^{\circ} \mathrm{C}\right)$. The uppermost supernatant was transferred to a new tube, and the RNA was precipitated by adding $500 \mu$ isopropanol. After centrifugation $\left(12,000 \times g, 8 \mathrm{~min},+4{ }^{\circ} \mathrm{C}\right)$, the precipitate was washed twice with $75 \%$ ethanol. The precipitates were stored under $75 \%$ ethanol at $-20{ }^{\circ} \mathrm{C}$ until processed further. After the ethanol was removed, the precipitates were let dry for 5 to $10 \mathrm{~min}$ at room temperature and dissolved in $200 \mu \mathrm{l}$ of 
Fig. 1 Experimental plan of the study. Livers of six brown trout (Salmo trutta) were dissected, transferred in two conditions, and stored at four temperatures before RNA extraction and RNA integrity (RIN) analysis (a). Black arrows refer to samples transported on ice, blue arrows to those transported in liquid nitrogen (LqN). Other experiments included freeze-thaw cycles of liver (b) and RNA (c) and incubation of the frozen liver in room temperature for nine periods of time (d) before RNA extraction and RIN analysis
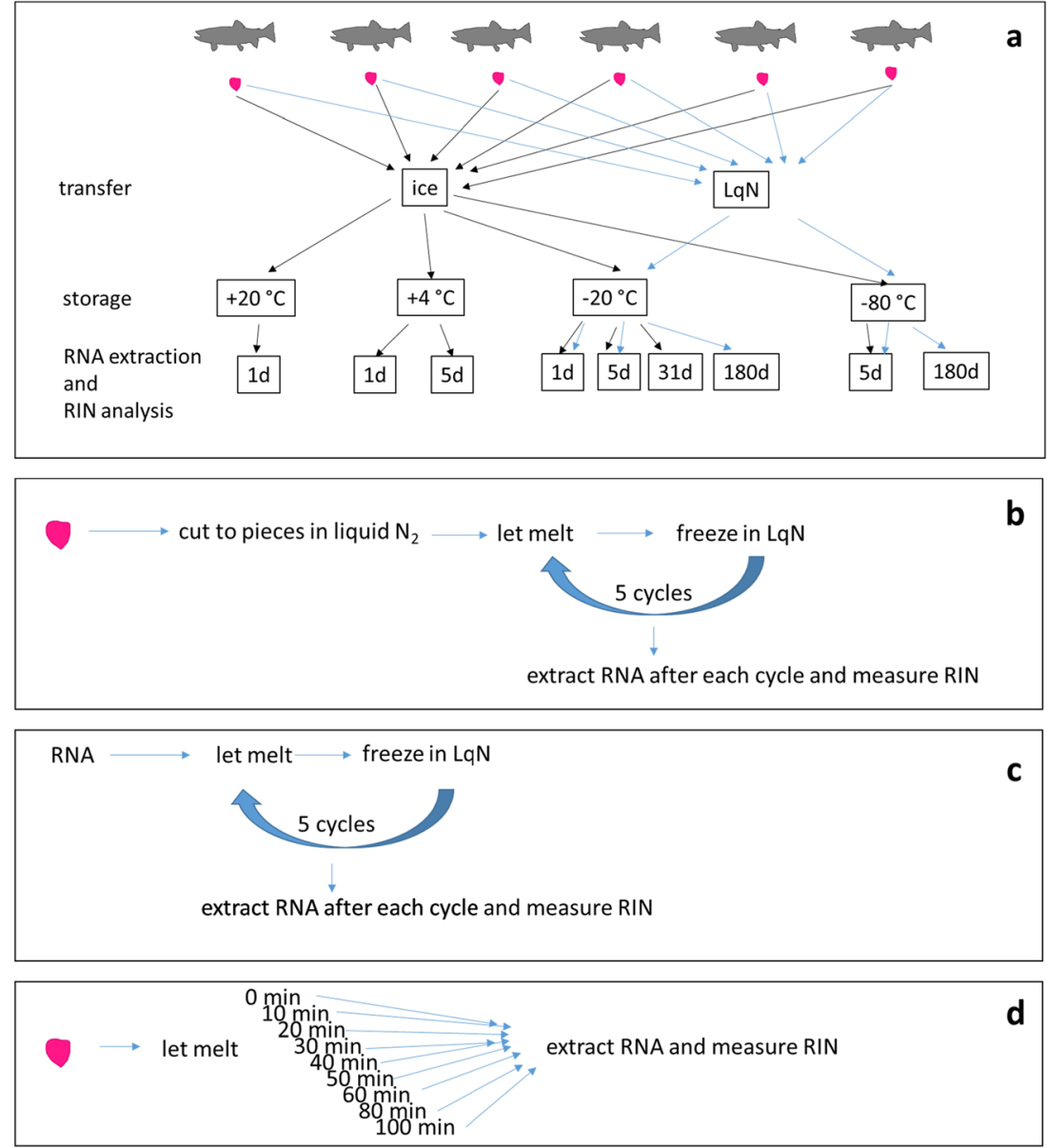

nuclease-free water (Thermo Fisher Scientific Inc.). The dissolved RNAs were stored at $-80{ }^{\circ} \mathrm{C}$.

\section{Assessment of RNA quality}

The concentration $\left(\mathrm{A}_{260}\right)$ and purity $\left(\mathrm{A}_{260} / \mathrm{A}_{280}, \mathrm{~A}_{260} / \mathrm{A}_{230}\right)$ of the RNAs were measured with NanoDrop 1000 (Thermo Fisher Scientific). When necessary, the RNAs were diluted to reach the concentration suitable for the RNA integrity analysis (25-500 ng).

The integrity of the RNAs was assessed with microchip electrophoresis using Eukaryote total RNA 6000 nano kit (Agilent) and BioAnalyzer (Agilent) according to the manufacturer's instructions. The software did not need modification for assessing RINs in brown trout samples.

\section{Freeze-thaw cycles of liver tissue}

Brown trout liver tissue (ca. $1.5 \mathrm{~g}$ pieces) stored in liquid nitrogen was cut to 50-100 mg pieces when still frozen (Fig. 1b). The pieces were let to melt in microcentrifuge tubes at room temperature ( 3 to $5 \mathrm{~min}$ ) and flash-frozen in liquid nitrogen. When the desired number of freeze-thaw cycles was obtained, the liver tissue was immediately homogenized on ice in Tri reagent and RNA extracted as described above.

\section{Freeze-thaw cycles of RNAs}

The purified RNAs from the liver of five individuals were thawed in total five times, and the integrity of the RNA was assessed after each freeze-thaw cycle (Fig. 1c). The RNAs were thawed at room temperature (ca. $5 \mathrm{~min}$ ) and transferred on ice immediately after melting. The RNAs remained unfrozen on ice for approximately $30 \mathrm{~min}$. After assessment of RNA integrity, the RNAs were moved back to $-80{ }^{\circ} \mathrm{C}$ and kept there for at least $4 \mathrm{~h}$ before the next melting.

\section{Room temperature incubation of liver tissues to obtain RNA with varying RINs}

Liver tissue from three BKME-exposed fish that had been stored in liquid nitrogen for 28 years, but still had good RNA quality (RIN >9.5), was taken to room temperature and let to melt. Pieces of 50 to $100 \mathrm{mg}$ were taken at $0 \mathrm{~min}$ 
(when the tissue was still frozen), and at 10, 20, 30, 40, 50, 60, 80 , and $100 \mathrm{~min}$, and the RNA was extracted with Tri reagent as described above.

\section{Quantitative reverse transcription PCR}

Quantitative reverse transcription PCR (RT-qPCR) runs were conducted for all room temperature incubated samples, for three new trout samples, and for historical samples that had a RIN $\geq 6$. As the historical pulp and paper mill effluents were known to contain substances that induce its transcription, $c y$ tochrome P450 1 a was chosen as the target gene. The primers were designed with AmplifX (version 1.5.4 by Nicolas Jullien; CNRS, Aix-Marseille Université-http://crn2m. univ-mrs.fr/pub/amplifx-dist) and checked for specificity with Primer-BLAST (http://www.ncbi.nlm.nih.gov/tools/ primer-blast/). The features of the primers are shown in Table 2. 60 S ribosomal protein $l 17$ (rl17) and nadh dehydrogenase 1 alpha subcomplex subunit 8 (ndufa8) were chosen as reference genes because their expression in effluentexposed and control brown trout was the most stable of a set of reference genes tested (Vehniäinen, unpublished).

After RNA extraction, $1 \mu \mathrm{g}$ of total RNA was treated with DNase (DNase I, RNase-free; Thermo) according to the manufacturer's instructions. The RNA was reverse transcribed to cDNA (iScript cDNA Synthesis Kit, Bio-Rad), after which the cDNAs were diluted $1+9$ with sterile water. Each RT-qPCR reaction consisted of $5 \mu \mathrm{l}$ of the diluted cDNA, $0.75 \mu \mathrm{l}$ of forward and reverse primers (final concentration $300 \mathrm{nmol}$ ), $6 \mu \mathrm{l}$ sterile water, and $12.5 \mu \mathrm{l}$ iQ SYBR Green Supermix (Bio$\mathrm{Rad})$. The reactions were run in duplicates in clear 96-well PCR plates (Bio-Rad), on a CFX96 Real-Time PCR cycler (Bio-Rad). The protocol was 3 min at $95{ }^{\circ} \mathrm{C} ; 40$ cycles $(10 \mathrm{~s}$ at $95{ }^{\circ} \mathrm{C}, 10 \mathrm{~s}$ at $58^{\circ} \mathrm{C}$, and $30 \mathrm{~s}$ at $\left.72{ }^{\circ} \mathrm{C}\right) ; 10 \mathrm{~s}$ at $95^{\circ} \mathrm{C}$ and melt curve from 65 to $95^{\circ} \mathrm{C}$. No template controls were run for all genes on all plates, and their cycles of threshold $\left(\mathrm{C}_{\mathrm{T}} \mathrm{s}\right)$ were always over 38 . Melt curves showed a single peak, confirming formation of only one PCR product. The expression values were calculated with the $2^{-\Delta \Delta C}$ T method, as the efficiencies of all genes were almost identical and close to 100\% (Livak and Schmittgen 2001).

\section{Statistics}

The effect of storage temperature and storage duration on RNA integrity was tested with two-way ANOVA followed by Tukey's test. The effect of transport temperature on RNA integrity was tested with repeated measures one-way ANOVA with a Greenhouse-Geisser correction for the samples stored at $-20^{\circ} \mathrm{C}$ and with $t$ test for the samples stored at $-80^{\circ} \mathrm{C}$.

Linear regression curves for $\mathrm{C}_{\mathrm{T}}$ as a function of sample melting time and RIN were drawn for each gene (cypla, ndufa, and rl17), using the data from the room temperature incubated historical liver samples. Analysis of covariance (ANCOVA) was used to compare the linear regressions for $\mathrm{C}_{\mathrm{T}}$ as a function of sample melting time between different genes (cypla, ndufa, rll7) to determine whether they were statistically similar. One-way ANOVA with repeated measures was used to test the effect of melting time on RIN. Because the data violated the assumption of sphericity, a GreenhouseGeisser correction was used.

$\log _{10}$ transformation was performed for the expression values to meet the requirements of ANOVA (normality, equal variance). One-way ANOVA followed by Tukey's test was used to test whether the effluent exposure had an effect on the levels of cyp $1 a$ mRNA. IBM SPSS Statistics 20 was used for the statistical analyses.

\section{Results}

\section{Storage length and temperature have an effect on RNA integrity}

High storage temperatures of liver samples resulted in poorquality RNA, whereas all storage temperatures below zero yielded RNA with RIN $>7$ (Table 1). Even the samples that had been preserved at $-20^{\circ} \mathrm{C}$ for 6 months had RINs $>7$ and could thus be considered suitable for RT-qPCR (Table 1). Both the length of storage and the storage temperature had an effect on RNA integrity (two-way ANOVA, $p<0.001$ for both). The RINs were different between all storage temperatures (Tukey, $p<0.001$ for all pairs). Transfer temperature

Table 2 Features of the primers used in the RT-qPCR

\begin{tabular}{|c|c|c|c|c|}
\hline Gene name & Accession & Primer sequence & Efficiency & Product length \\
\hline $60 S$ ribosomal protein $l 17$ (rl17) & NM_001195159.1 & $\begin{array}{l}\text { F: atcgagcacatccaggtcaacaag } \\
\text { R: aatgtggcaaggggagctcatgta }\end{array}$ & 100.3 & 99 \\
\hline $\begin{array}{l}\text { nadh dehydrogenase } 1 \text { alpha subcomplex } \\
\text { subunit } 8 \text { (ndufa } 8 \text { ) }\end{array}$ & NM_001160582.1 & $\begin{array}{l}\text { F: ttcagagcctcatcttgcctgct } \\
\text { R: caacatagggattggagagctgtacg }\end{array}$ & 101.1 & 119 \\
\hline Cytochrome P450 1 a (cypla) & U62796 & $\begin{array}{l}\text { F: cagtccgccaggctcttatcaagc } \\
\text { R: gecaagctcttgcegtcgttgat }\end{array}$ & 102.2 & 94 \\
\hline
\end{tabular}


(ice/liquid nitrogen for $4 \mathrm{~h}$ ) had an effect on RIN in samples stored at $-20^{\circ} \mathrm{C}$ (ANOVA with repeated measures, $p=0.05$ ) but not in those stored at $-80{ }^{\circ} \mathrm{C}(t$ test, $p>0.05)$.

\section{Freeze-thaw cycles of tissue or RNA do not compromise the integrity of RNA}

Freeze-thaw cycles had no effect on RNA integrity. The RNA extracted from liver samples that had been thawed five times was still intact with RIN >9.5 (Table 3). Similarly, purified RNA remained un-degraded after five freeze-thaw cycles (Table 3).

\section{Room temperature incubation of samples has an effect on RNA integrity and RT-qPCR results}

Thawing the frozen liver tissue at room temperature caused a time-dependent deterioration in RNA integrity (repeated measures ANOVA with a Greenhouse-Geisser correction, $p=$ 0.001) (Fig. 2). When qPCR was run for these samples, it was seen that the RNA degradation had an effect on $C_{T}$ values and the effect was different between genes. The mRNA of the target gene cypla seemed to degrade more slowly than those of the reference genes, as the slopes of the linear regression curves of $\mathrm{C}_{\mathrm{T}}$ as a function of sample melting time were different between cypla and ndufa (ANCOVA, $p=0.014$ ) and cypla and $r l 17$ (ANCOVA, $p=0.018$ ) (Fig. 3, Table 4). The slopes of the reference genes did not differ from each other (ANCOVA, $p=0.963$ ). The more degraded the RNA (the lower the RIN) was, the higher the $\mathrm{C}_{\mathrm{T}}$ value of every gene, which means that less target was present in the samples with a lower RIN (Fig. 4).

\section{Similar cyp1a expression in all treatments in the historical samples, but significantly lower in new samples}

The cypla expression did not differ between treatments in the historical liver samples of brown trout (Fig. 5). Using samples with similar RINs (6-7) did not markedly change the results (no changes in statistical significance) (Fig. 5).The cypla

Table 3 The effect of thawing on RIN values in brown trout liver samples and extracted RNA. RIN values represent mean \pm SD of five (liver sample) or six (purified RNA) biological replicates

\begin{tabular}{llc} 
Number of freeze-thaw cycles & Liver sample RIN & Purified RNA RIN \\
\hline 1 & $9.7 \pm 0.2$ & $10.0 \pm 0.0$ \\
2 & $9.7 \pm 0.1$ & $9.5 \pm 0.2$ \\
3 & $9.8 \pm 0.3$ & $9.6 \pm 0.2$ \\
4 & $9.7 \pm 0.2$ & $9.9 \pm 0.1$ \\
5 & $9.7 \pm 0.2$ & $9.8 \pm 0.1$ \\
\hline
\end{tabular}

mRNA levels were an order of magnitude higher in the historical control samples of unexposed brown trout than the new ones (Table 5). The magnitude of difference depended on the reference genes used, because the $\mathrm{C}_{\mathrm{T}}$ values of $\mathrm{rll} 7 \mathrm{w}$ were remarkably higher in the historical samples than the new ones. While the cyp $1 a$ expression was almost 30 times higher in the historical than the new samples when both ndufa and $r l 17$ were used as reference genes, it was only 12 times higher when $n d u f a$ was the only reference gene (Table 5 ).

\section{Discussion}

\section{Effect of storage conditions}

The higher the storage temperature and the longer the time of storage, the more degraded the liver RNA of brown trout was. In this study, the RNA had nearly completely degraded in samples left at room temperature for $24 \mathrm{~h}$ (mean RIN <3). Preservation of samples at $+4{ }^{\circ} \mathrm{C}$ caused significant RNA degradation in $24 \mathrm{~h}$ (mean RIN $<7$ ) and nearly complete loss of integrity in 5 days (mean RIN <4). Previous studies have shown that it may be possible to extract good-quality RNA from human and rat tissues kept at room temperature for several hours after surgical removal (Bao et al. 2013; Micke et al. 2006; Ohashi et al. 2004; Thompson et al. 2007). However, controversial results have also been obtained, for example, 45 min room temperature preservation was enough to cause substantially more RNA degradation than $\leq 30 \mathrm{~min}$ (Viana et al. 2013). There are also observations that the vulnerability to RNA degradation during storage at room temperature may depend on tissue in both poikilotherms and homeotherms (Ibberson et al. 2009; Seear and Sweeney 2008; Viana et al. 2013). RNA may degrade very rapidly in tissues with high RNase activity, such as the pancreas, spleen, and lungespecially if there is any tissue damage so that the RNases stored in intracellular vesicles are released (Chirgwin et al. 1979). Our results with liver are applicable to tissues with low RNase content, such as the kidney, heart, and brain. As routine precaution preclude, it is advisable to avoid storing the samples at room temperature and in the fridge if good-quality RNA is needed.

Unexpectedly, no information was found in the published literature about the effect of $-20^{\circ} \mathrm{C}$ storage on RNA integrity. Surprisingly, the RNA extracted from the liver stored at $20^{\circ} \mathrm{C}$ for 6 months was still rather intact ( $\mathrm{RIN} \geq 7$ ). A normal freezer may thus be suitable for short-time preservation if a deep freezer is not available. Long-time preservation of samples at $-80^{\circ} \mathrm{C}$ is recommended, as other studies have found that RNA integrity is not compromised by several years of storage at $-80{ }^{\circ} \mathrm{C}$ (Andreasson et al. 2013; Bao et al. 2013; Mathieson et al. 2016; Rudloff et al. 2010). 
Fig. 2 Melting the samples deteriorates the quality of sample RNA in a time-dependent manner. Three brown trout (Salmo trutta) livers that had been preserved in liquid nitrogen for 28 years were left to melt at room temperature, and samples collected at 0 to $100 \mathrm{~min}$. RNA was extracted and RIN values assessed. RIN as a function of melting time (a). Representative electropherograms (b) of RIN 9.7 (219.0), RIN 8.9 (219.2), RIN 6.9 (219.4), and RIN 5.9 (219.7)

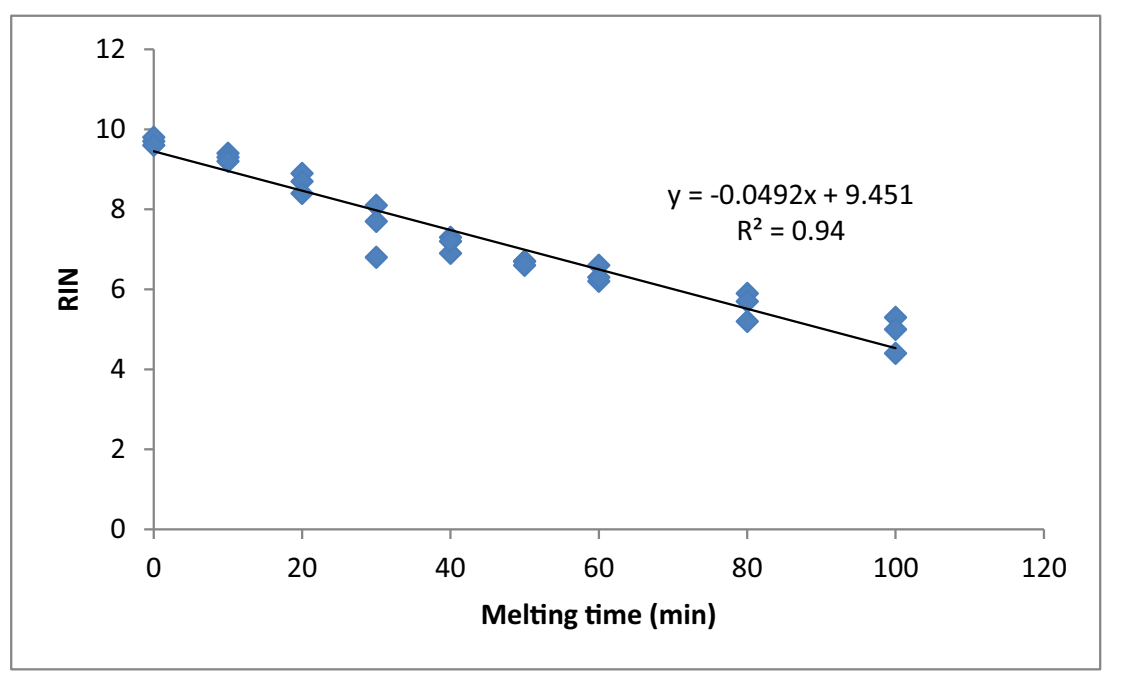

a

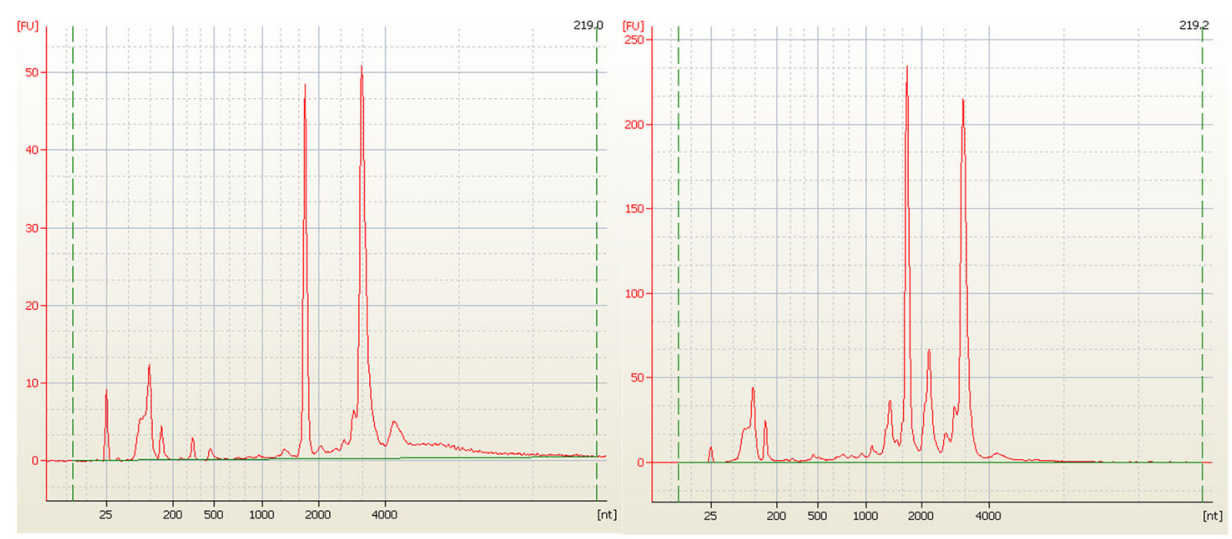

b
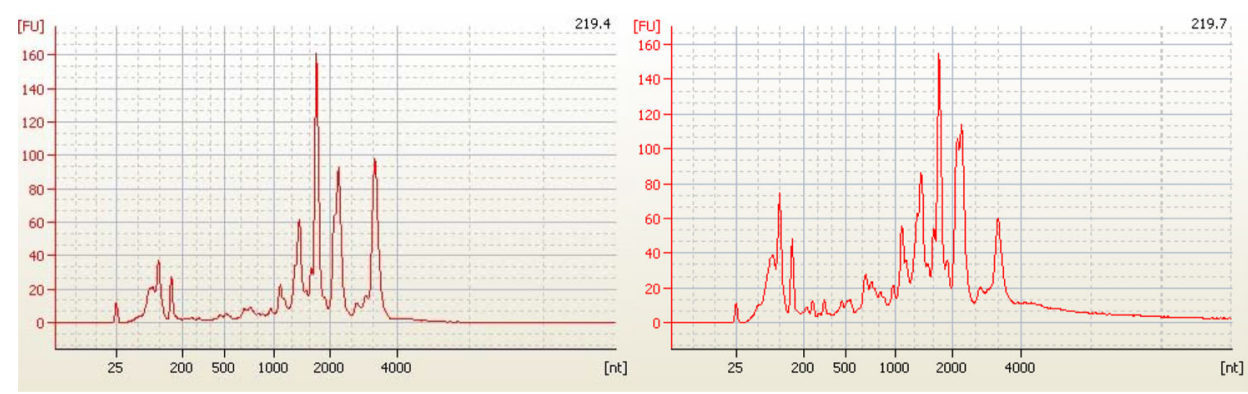

\section{Freeze-thaw cycles}

Neither the freeze-thaw cycles of tissue nor the freeze-thaw cycles of purified RNA affected the integrity of RNA in brown trout liver samples. Previous studies on homeotherms have shown that freeze-thaw cycles themselves do not degrade RNA, but it is the time the RNA remains unfrozen that plays a role (Botling et al. 2009; Jochumsen et al. 2007; Thompson et al. 2007). The same seems to hold true for poikilotherms as well. A study with biobanked human half brains showed that the more times the brain had been sampled, the more degraded the RNA was (Sherwood et al. 2011). Though this result may seem controversial to ours, it was probably not the physical freeze-thawing that caused the degradation, as it can be speculated that the more times the brain had been sampled the longer it had remained unfrozen. Our results are applicable to samples that have intact RNA at the start of the preservation. Freezethaw cycles of low-quality samples may lead to more RNA degradation, as the RNases may have been released from cells before initial freezing. Based on our results, it can be concluded that both the samples and the extracted RNA may be thawed and frozen at least five times without compromising the RNA integrity, if the samples are of good quality (have been freshly frozen) and if the samples remain unfrozen on ice only for a short time (e.g., 30 min for tissue samples with low RNase content, $150 \mathrm{~min}$ for extracted RNA). 

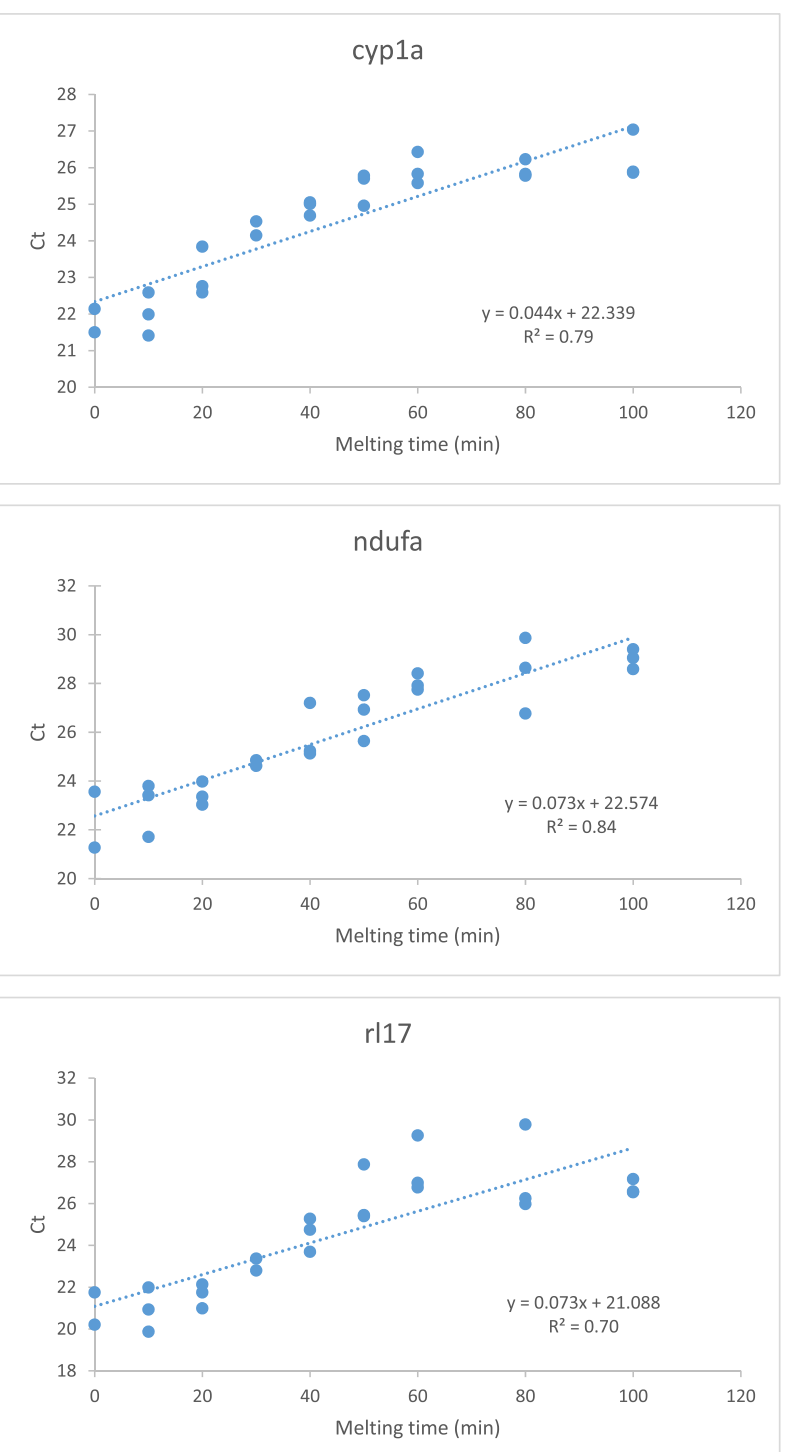

Fig. 3 Melting of the samples affects the CT values. Three brown trout (Salmo trutta) livers that had been preserved in liquid nitrogen for 28 years were left to melt at room temperature, and samples collected at 0 to $100 \mathrm{~min}$. RNA was extracted, reverse transcribed to cDNA, and qPCR was run with three genes. The figures present observed CT values plotted against melting time for the target gene cyp1a (a), ndufa (b), and rl17 (c) with their linear regression lines, their functions, and $R^{2}$ values

Table 4 Slopes of the linear regression lines of $\mathrm{C}_{\mathrm{T}}$ values plotted against melting time of the liver sample and their $95 \%$ confidence intervals for target (cypla) and reference (ndufa, rl17) genes. The slopes of genes denoted with the same letter $(a, b)$ do not differ statistically from each other (ANCOVA, $p>0.05$ )

\section{Gene}

Slope B, (95\% confidence intervals)

\begin{tabular}{ll}
\hline cypla & $0.044(0.025,0.063) \mathrm{a}$ \\
ndufa & $0.073(0.059,0.087) \mathrm{b}$ \\
rl17 & $0.073(0.055,0.090) \mathrm{b}$
\end{tabular}

a
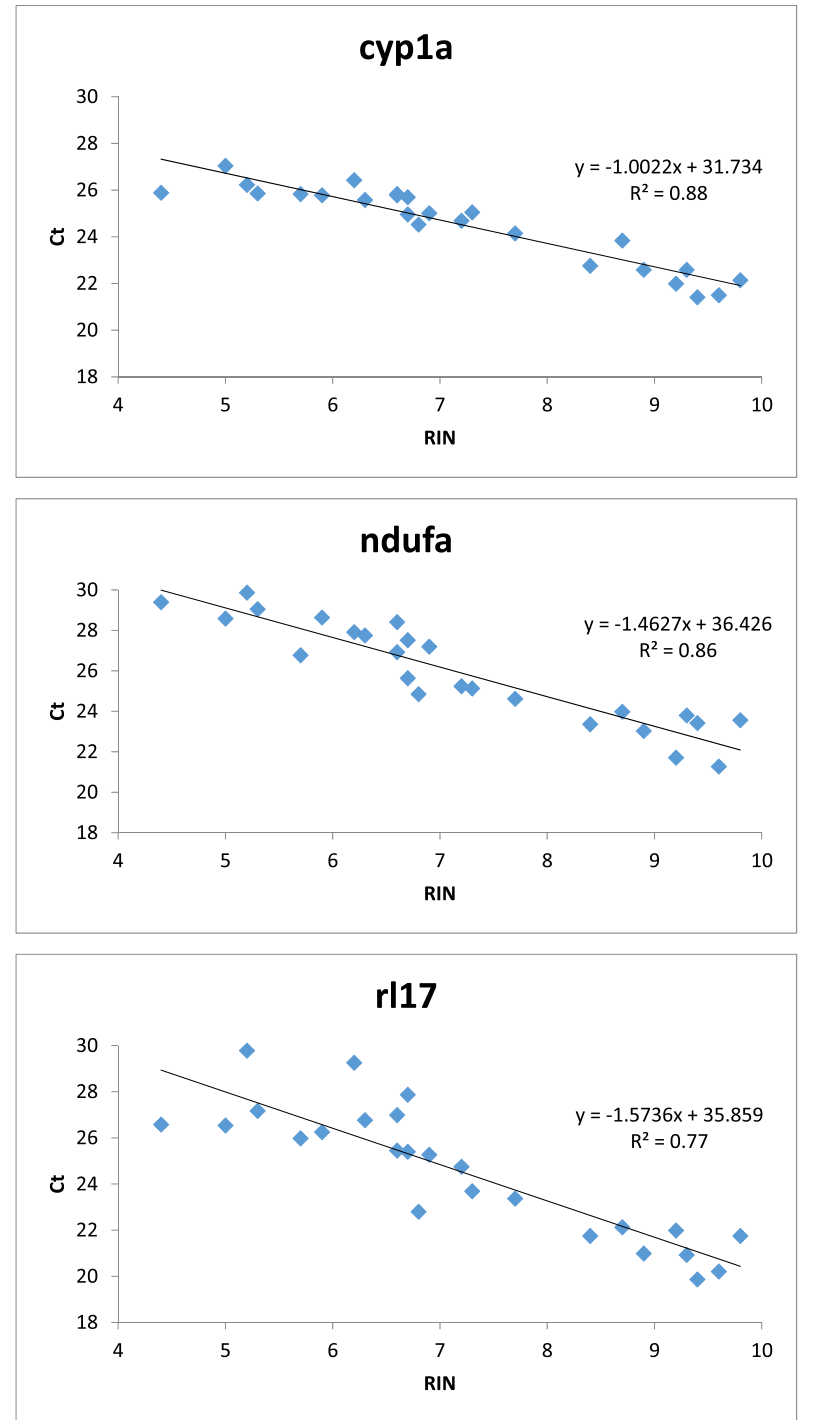

Fig. 4 RNA degradation has an effect on CT values, and the effect is different between genes. Three brown trout (Salmo trutta) livers that had been preserved in liquid nitrogen for 28 years were left to melt at room temperature, and samples collected at 0 to $100 \mathrm{~min}$ to get identical samples with a varying degree of RNA degradation. RNA was extracted, reverse transcribed to cDNA, and qPCR was run with three genes. The figures present observed CT values plotted against RIN for the target gene cypla (a), ndufa (b), and rl17 (c) with their linear regression lines, their functions, and $R^{2}$ values

\section{RNA degradation may affect RT-qPCR results}

In our study with a poikilothermic animal, RIN correlated well with $C_{T}$ values: the lower the RIN value was, the higher the $C_{T}$ value. This means signal detection at a later cycle, corresponding to less target sequence in the sample. Also, previous studies have shown that RNA degradation correlates with $\mathrm{C}_{\mathrm{T}}$ values (Botling et al. 2009; Fleige et al. 2006; Koppelkamm et al. 2011; Perez-Novo et al. 2005; Vermeulen et al. 2011). However, RIN is greatly influenced by the degradation of ribosomal RNA, which does not always correlate well with 


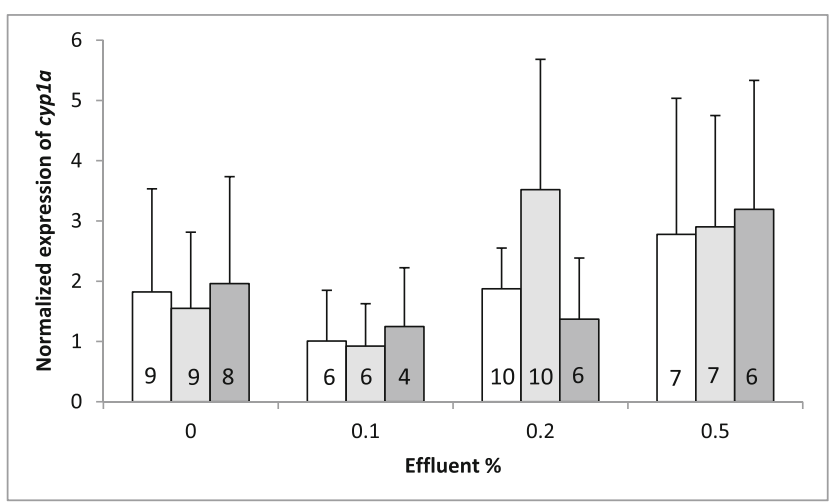

Fig. 5 cypla gene expression in the liver of brown trout (Salmo trutta) exposed to dilutions of pulp and paper mill effluents for 4 months in 1984 . The white columns represent measured expression values of samples with $\mathrm{RIN} \geq 6$, the light gray ones represent expression values calculated from RIN-corrected CT values of samples with RIN $\geq 6$, and the dark gray ones represent measured expression values of samples with RIN 6-7. Data is presented as mean $+\mathrm{SD}$. Number of analyzed samples is shown inside the columns

the degradation of mRNA. For example, the correlation between RIN and $\mathrm{C}_{\mathrm{T}}$ is poor in formalin-fixed paraffin-embedded samples (Kashofer et al. 2013). In mammalian samples, warm ischemia after removal of the tissue may have large effects on gene expression (Huang et al. 2001). This means that the $C_{T}$ values may increase or decrease depending on the gene, and there is no correlation between $\mathrm{C}_{\mathrm{T}}$ and RIN of the samples (Huang et al. 2001). In the present study, the fish were taken from cold water and the sampling procedure was performed in a low-temperature room. It is, however, of great importance to minimize the time between tissue removal and flash freezing.

The room temperature incubation affected the target gene cypla less than the two reference genes $n d u f a$ and $r l 17$, which may mean that the mRNA of cypla degraded more slowly than those of the reference genes. These results are in agreement with earlier research showing that the magnitude of the effect of RNA degradation on $\mathrm{C}_{\mathrm{T}}$ values may depend on gene (Botling et al. 2009; Fleige et al. 2006; Huang et al. 2013; Koppelkamm et al. 2011; Perez-Novo et al. 2005; Skrypina et al. 2003; Vermeulen et al. 2011). As the $\mathrm{C}_{\mathrm{T}}$ value of cypla increases slower than the $\mathrm{C}_{\mathrm{T}}$ values of the two reference genes when the RNA degrades, cypla expression will be

Table 5 Normalized expression of cypla in control brown trout from the 1984 study, and in brown trout of the same sex and approximately same age, sacrificed in 2012. Data is expressed as mean \pm SD. $N=3$ in both groups

\begin{tabular}{lll}
\hline & $\begin{array}{l}\text { cypla expression, } \\
\text { reference genes } n d u f a \\
\text { and } r l 17\end{array}$ & $\begin{array}{l}\text { cypla expression, } \\
\text { reference gene } n d u f a\end{array}$ \\
\hline $\begin{array}{l}\text { Historical control } \\
\text { samples }\end{array}$ & $0.86 \pm 0.38$ & $1.4 \pm 0.7$ \\
New samples & $0.03 \pm 0.01$ & $0.12 \pm 0.07$ \\
\hline
\end{tabular}

overestimated in samples with low RIN values. It has been noticed that mammalian cypla mRNA may be extremely resistant to degradation (Skrypina et al. 2003). When oligo dT primers are used in the RT reaction, amplicons closer to $3^{\prime}$ end tend to degrade faster (Skrypina et al. 2003). In our work, primers were a mixture of oligo $\mathrm{dT}$ and random primers, and therefore the location of the amplicon respective to $3^{\prime}$ end may play a role. Another possible reason for the seemingly different degradation rate is that the ndufa and $r l 17$ amplicons are longer than the cypla amplicon. Moreover, there are observations that RNases may prefer certain sequences over others when they degrade RNA - even the most abundant form, RNase A (Boix et al. 2013; Wang et al. 2008). To avoid the possible biasing effect of differences created by RNA degradation, it is best to use samples with as intact RNA as possible, and with similar RINs, in transcriptomic analyses.

\section{cyp 1a expression in historical and new samples}

The historical samples of the control group fish showed remarkably higher cypla levels than the new ones. Though some of this difference could be explained by higher levels of the reference gene $r l 17$ in the new samples, there was still a difference by an order of magnitude when only ndufa was used as a reference gene. The historical and new fish were all of approximately the same age, but they originated from different stocks, which may play a role in the difference. However, a more likely explanation is the feed of the fish: The historical samples were from fish that, in addition to dry fish feed, had been fed with Baltic herring (Clupea harengus L.) (Vuorinen and Vuorinen 1985). At the time of the study, the Baltic herring contained significant amounts of dioxins and other persistent aryl hydrocarbon receptor (AhR) activators as can be judged from the total PCB concentrations in Baltic salmon, which prey on herring, from the 1980s to 2000s, 6.7 and $1.8 \mathrm{mg} \mathrm{kg}^{-1}$ (in fat), respectively (Vuorinen et al. 1985; Vuorinen et al. 2012).

Induction of CYP1A mRNA, protein, and activity levels is a biomarker of exposure to BKME in fishes (Gagnon et al. 1994; Kloepper-Sams and Benton 1994; Munkittrick et al. 1992; Soimasuo et al. 1995). Though a trend for increasing expression of cypla with increasing BKME concentration was seen in the historical samples investigated in this study, there was no statistically significant difference between treatments. Thus, one can conclude that either the effluent did not contain effective amounts of AhR activators, or the high basal cypla level (as seen in the control group fish) masked the effect of the effluent. Another possibility is that the BKME effluent contained estrogen-like compounds that repressed cypla expression (Navas and Segner 2001; Stegeman et al. 1982). The recruitment of the fish was compromised at 0.2 and $0.5 \%$ BKME effluent dilutions, which may point to disturbance of the steroid hormone pathways (Vuorinen, P. J. and Vuorinen 1985). 


\section{Recommendations for the preservation and handling of fish samples and RNA for transcriptomic analyses}

Storage: Store tissue and RNA designated for transcriptomic analyses at $-80{ }^{\circ} \mathrm{C}$. Short-time storage at $-20{ }^{\circ} \mathrm{C}$ may be adequate for samples with low RNase content if $-80^{\circ} \mathrm{C}$ storage is not available.

Freeze-thaw cycles: Liver tissue and purified RNA can be thawed at least five times without significant degradation of RNA, if the tissue samples have been frozen immediately after sampling, and if the time that the tissue or RNA remains unfrozen is kept in minimum.

Transcriptomic analyses: It is important to treat all samples in a similar way during sampling and storage. As different transcripts may degrade in a different way, we recommend using only samples with minimal degradation (as high RIN values as possible), and with similar RIN values.

These recommendations apply to tissues with relatively low RNase activity, such as the liver, kidney, and brain. Tissues with high RNase content (spleen, pancreas, stomach) may need to be treated in a different way to obtain goodquality RNA.

Acknowledgments Open access funding provided by University of Jyväskylä (JYU). The authors would like to thank Mervi Koistinen and Leena Siitonen for technical assistance. The anonymous reviewers are acknowledged for helpful comments.

Funding information The research was funded by the University of Jyväskylä and Academy of Finland (285296 to ERV).

Open Access This article is distributed under the terms of the Creative Commons Attribution 4.0 International License (http:// creativecommons.org/licenses/by/4.0/), which permits unrestricted use, distribution, and reproduction in any medium, provided you give appropriate credit to the original author(s) and the source, provide a link to the Creative Commons license, and indicate if changes were made.

\section{References}

Andreasson A, Kiss NB, Juhlin CC, Höög A (2013) Long-term storage of endocrine tissues at $-80^{\circ} \mathrm{C}$ does not adversely affect RNA quality or overall histomorphology. Biopreserv Biobank 11:366-370

Bao W, Zhang X, Zhang J, Zhou W, Bi T, Wang J, Yan W, Lin A (2013) Biobanking of fresh-frozen human colon tissues: impact of tissue ex-vivo ischemia times and storage periods on RNA quality. Ann Surg Oncol 20:1737-1744

Boix E, Blanco JA, Nogués MV, Moussaoui M (2013) Nucleotide binding architecture for secreted cytotoxic endoribonucleases. Biochimie 95:1087-1097

Botling J, Edlund K, Segersten U, Tahmasebpoor S, Engstrom M, Sundstrom M, Malmstrom P, Micke P (2009) Impact of thawing on RNA integrity and gene expression analysis in fresh frozen tissue. Diagn Mol Pathol 18:44-52

Chirgwin JM, Przybyla AE, MacDonald RJ, Rutter WJ (1979) Isolation of biologically active ribonucleic acid from sources enriched in ribonuclease. Biochemistry (N Y ) 18:5294-5299
Ervin JF, Heinzen EL, Cronin KD, Goldstein D, Szymanski MH, Burke JR, Welsh-Bohmer KA, Hulette CM (2007) Postmortem delay has minimal effect on brain RNA integrity. J Neuropathol Exp Neurol 66:1093-1099

Fleige S, Pfaffl MW (2006) RNA integrity and the effect on the real-time qRT-PCR performance. Mol Asp Med 27:126-139

Fleige S, Walf V, Huch S, Prgomet C, Sehm J, Pfaffl MW (2006) Comparison of relative mRNA quantification models and the impact of RNA integrity in quantitative real-time RT-PCR. Biotechnol Lett 28:1601-1613

Gagnon MM, Dodson JJ, Hodson PV, Vanderkraak G, Carey JH (1994) Seasonal effects of bleached kraft mill effluent on reproductive parameters of white sucker (Catostomus commersoni) populations of the St-Maurice River, Quebec, Canada. Can J Fish Aquat Sci 51: 337-347

Gallego Romero I, Pai A, Tung J, Gilad Y (2014) RNA-seq: impact of RNA degradation on transcript quantification. BMC Biol 12:42

Huang J, Qi R, Quackenbush J, Dauway E, Lazaridis E, Yeatman T (2001) Effects of ischemia on gene expression. J Surg Res 99: 222-227

Huang X, Baumann M, Nikitina L, Wenger F, Surbek D, Körner M, Albrecht C (2013) RNA degradation differentially affects quantitative mRNA measurements of endogenous reference genes in human placenta. Placenta 34:544-547

Ibberson D, Benes V, Muckenthaler M, Castoldi M (2009) RNA degradation compromises the reliability of microRNA expression profiling. BMC Biotechnol 9:102

Imbeaud S, Graudens E, Boulanger V, Barlet X, Zaborski P, Eveno E, Mueller O, Schroeder A, Auffray C (2005) Towards standardization of RNA quality assessment using user-independent classifiers of microcapillary electrophoresis traces. Nucleic Acids Res 33:e56

Jochumsen KM, Tan Q, Dahlgaard J, Kruse TA, Mogensen O (2007) RNA quality and gene expression analysis of ovarian tumor tissue undergoing repeated thaw-freezing. Exp Mol Pathol 82:95-102

Kashofer K, Viertler C, Pichler M, Zatloukal K (2013) Quality control of RNA preservation and extraction from paraffin-embedded tissue: implications for RT-PCR and microarray analysis. PLoS One 8(e70714):e70714-e70714

Kloepper-Sams PJ, Benton E (1994) Exposure of fish to biologically treated bleached-kraft effluent. 2. Induction of hepatic cytochromeP4501a in mountain whitefish (Prosopium williamsoni) and other species. Environ Toxicol Chem 13:1483-1496

Koppelkamm A, Vennemann B, Lutz-Bonengel S, Fracasso T, Vennemann M (2011) RNA integrity in post-mortem samples: influencing parameters and implications on RT-qPCR assays. Int J Legal Med 125:573-580

Livak KJ, Schmittgen TD (2001) Analysis of relative gene expression data using real-time quantitative PCR and the $2-\Delta \Delta C T$ method. Methods 25:402-408

Mathieson W, Betsou F, Myshunina T, Pushkarev V, Pushkarev V, Shinkarkina A, Voskoboynyk L, Thomas GA (2016) The effect of long-term $-80^{\circ} \mathrm{C}$ storage of thyroid biospecimens on RNA quality and ensuring fitness for purpose. J Clin Pathol 69:1105-1108

Micke P, Ohshima M, Tahmasebpoor S, Ren Z, Ostman A, Ponten F, Botling J (2006) Biobanking of fresh frozen tissue: RNA is stable in nonfixed surgical specimens. Lab Investig 86:202-211

Munkittrick KR, Vanderkraak GJ, Mcmaster ME, Portt CB (1992) Response of hepatic MFO activity and plasma sex steroids to secondary-treatment of bleached kraft pulp-mill effluent and mill shutdown. Environ Toxicol Chem 11:1427-1439

Navas JM, Segner H (2001) Estrogen-mediated suppression of cytochrome P4501A (CYP1A) expression in rainbow trout hepatocytes: role of estrogen receptor. Chem Biol Interact 138:285-298

Ohashi Y, Creek K, Pirisi L, Kalus R, Young S (2004) RNA degradation in human breast tissue after surgical removal: a time-course study. Exp Mol Pathol 77:98-103 
Perez-Novo C, Claeys C, Speleman F, Van Cauwenberge P, Bachert C, Vandesompele $\mathrm{J}$ (2005) Impact of RNA quality on reference gene expression stability. Biotechniques 39:52, 54, 56

Rudloff U, Bhanot U, Gerald W, Klimstra DS, Jarnagin WR, Brennan MF, Allen PJ (2010) Biobanking of human pancreas cancer tissue: impact of ex-vivo procurement times on RNA quality. Ann Surg Oncol 17:2229-2236

Sambrook J, Russell DW (2001) Molecular cloning: a laboratory manual (3-volume set). Cold Spring Harbor Laboratory Press, Cold Spring Harbor

Schroeder A, Mueller O, Stocker S, Salowsky R, Leiber M, Gassmann M, Lightfoot S, Menzel W, Granzow M, Ragg T (2006) The RIN: an RNA integrity number for assigning integrity values to RNA measurements. BMC Mol Biol 7:3

Seear PJ, Sweeney GE (2008) Stability of RNA isolated from postmortem tissues of Atlantic salmon (Salmo salar L.). Fish Physiol Biochem 34:19-24

Sherwood KR, Head MW, Walker R, Smith C, Ironside JW, Fazakerley JK (2011) RNA integrity in post mortem human variant CreutzfeldtJakob disease (vCJD) and control brain tissue. Neuropathol Appl Neurobiol 37:633-642

Skrypina NA, Timofeeva AV, Khaspekov GL, Savochkina LP, Beabealashvilli RS (2003) Total RNA suitable for molecular biology analysis. J Biotechnol 105:1-9

Soimasuo R, Jokinen I, Kukkonen J, Petanen T, Ristola T, Oikari A (1995) Biomarker responses along a pollution gradient - effects of pulp and paper-mill effluents on caged whitefish. Aquat Toxicol 31: 329-345

Stegeman JJ, Pajor AM, Thomas P (1982) Influence of estradiol and testosterone on cytochrome P-450 and monooxygenase activity in immature brook trout, Salvelinus fontinalis. Biochem Pharmacol 31: 3979-3989

Thompson KL, Pine PS, Rosenzweig BA, Turpaz Y, Retief J (2007) Characterization of the effect of sample quality on high density oligonucleotide microarray data using progressively degraded rat liver RNA. BMC Biotechnol 7:57

Vermeulen J, De Preter K, Lefever S, Nuytens J, De Vloed F, Derveaux S, Hellemans J, Speleman F, Vandesompele J (2011) Measurable impact of RNA quality on gene expression results from quantitative PCR. Nucleic Acids Res 39:e63

Viana CR, Scapulatempo Neto C, Kerr LM, Palmero EI, Chiquitelli Marques MM, Colaiacovo T, de Queiroz Junior AF, Carvalho AL, Coelho Siqueira SA (2013) The interference of cold ischemia time in the quality of total RNA from frozen tumor samples. Cell Tissue Bank 14:167-173

Vuorinen PJ, Vuorinen M (1985) Effects of bleached kraft mill effluent on reproduction of brown trout Salmo trutta on a restricted diet. Finn Fish Res 6:92-105

Vuorinen PJ, Paasivirta J, Piilola T, Surmaaho K, Tarhanen J (1985) Organochlorine compounds in Baltic salmon and trout.1. Chlorinated hydrocarbons and chlorophenols 1982. Chemosphere 14:1729-1740

Vuorinen PJ, Keinanen M, Kiviranta H, Koistinen J, Kiljunen M, Myllyla T, Ponni J, Peltonen H, Verta M, Karjalainen J (2012) Biomagnification of organohalogens in Atlantic salmon (Salmo salar) from its main prey species in three areas of the Baltic Sea. Sci Total Environ 421:129-143

Walter M, Seboek D, Demougin P, Bubendorf L, Oberholzer M, MullerBrand J, Muller B (2006) Extraction of high-integrity RNA suitable for microarray gene expression analysis from long-term stored human thyroid tissues. Pathology 38:249-253

Wang X, Wang G, Shen C, Li L, Wang X, Mooney S, Edenberg H, Sanford J, Liu Y (2008) Using RNase sequence specificity to refine the identification of RNA-protein binding regions. BMC Genomics 9:S17

Weis S, Llenos IC, Dulay JR, Elashoff M, Martínez-Murillo F, Miller CL (2007) Quality control for microarray analysis of human brain samples: the impact of postmortem factors, RNA characteristics, and histopathology. J Neurosci Methods 165:198-209

Publisher's note Springer Nature remains neutral with regard to jurisdictional claims in published maps and institutional affiliations. 